\title{
ВИКОРИСТАННЯ ОНЛАЙН РЕСУРСІВ ДЛЯ ПІДГОТОВКИ МАЙБУТНІХ УЧИТЕЛІВ
}

\author{
Оксана Ступак \\ доктор педагогічних наук, доцент кафедри менеджменту \\ ДВНЗ «Донбаський державний педагогічний університет» \\ м. Слов'янськ, Україна \\ ORCID ID 0000-0001-6732-4569 \\ stupak.oksana.ua@gmail.com
}

\begin{abstract}
Анотація. У статті представлено теоретичний аналіз електронних освітніх ресурсів для підготовки здобувачів вищої педагогічної освіти, підібрано низку платформ для створення електронних інструментів освітнього процесу: інтерактивні презентації, онлайн-дошки, онлайн-ігри, вебквести, вікторини, тести, пазли, ментальні карти. На онлайн-дошках можна фіксувати картинки, документи, робити записи, малювати, виконувати спільні завдання. Онлайн-ігри підвищують ефективність освітнього процесу, маючи чітко визначені цілі, завдання та вектор спрямування. Використання вебквестів успішно моделює професійно зорієнтовані завдання, виконання яких вимагає залучення колективу однодумців до аналітичної, креативної діяльності, зокрема за допомогою усної та писемної комунікації. Створення онлайн-пазлів сприяє формуванню вміння концентрувати увагу, систематизувати та аналізувати наявну інформацію. Ментальні карти використовують техніки візуалізації мислення та фіксації інформації, графічного зображення структури понять.
\end{abstract}

Ключові слова: ресурси; вебквести; пазли; тести; онлайн-ігри.

Постановка проблеми в загальному вигляді. В умовах вимушеної дистанційної освіти під час пандемії COVID-19 заклади освіти стикнулися 3 новими викликами. Майже весь навчальний рік здобувачі вищої педагогічної освіти опановували нові знання онлайн, а науково-педагогічні працівники адаптували освітні програми до дистанційної форми. Звичайно якість навчального процесу на перших етапах дещо знизилась, проте мобілізація свого освітнього, наукового та виховного потенціалу викладачів дала можливість продовжувати якісний освітній процес. Важливим питанням при цьому постав пошук дієвих, інтерактивних електронних ресурсів, платформ, інструментів, методів, що сприяли б ефективному засвоєнню знань здобувачів вищої освіти, зокрема й майбутніх учителів.

Аналіз останніх досліджень і публікацій. Теоретичний доробок наукових розвідок у напряму використання електронних освітніх ресурсів під час підготовки здобувачів вищої освіти свідчить про актуальність теми як серед вітчизняних, так і закордонних науковців. Використання онлайн інструментів безпосередньо не пов'язана 3 формуванням знань та вмінь. Це впливає на поведінку здобувачів, підвищує їх працездатність та мотивацію і, отже, може

() ДВНЗ «Донбаський державний педагогічний університет» 


\section{О. СТУПАК}

Використання онлайн ресурсів для підготовки майбутніх учителів

призвести до вдосконалення знань та навичок. Програми та елементи ігрових моделей використовуються в бізнесі вже давно, але з наукової точки зору метод гейміфікації був вперше переглянутий лише у 2010 р. в Сполучених Штатах Америки. В останні роки індустрія гейміфікації інтенсивно розвивається, а також знаходить можливості для реалізації своїх продуктів. Послуги гейміфікації розподіляються в різних сферах, особливо розваги, роздрібна торгівля, виробництво, засоби масової інформації, видавнича справа. В останнє десятиліття ця інноваційна технологія була впроваджена в освіту з метою збільшення участі здобувачів вищої освіти в освітньому процесі, розвитку інтерактивності під час навчання, що передбачає взаємозв'язок викладача та здобувачів, а також здобувачів між собою. Термін «гейміфікація» означає використання динамічної та ігрової механіки для залучення людей до системи, у даному випадку залучення здобувачів вищої освіти до освітньої діяльності. Гейміфікація - це багатоманітне соціально-технологічне явище зі значним потенціалом забезпечити безліч переваг, таких як соціальна взаємодія, згуртованість, мотивація навчання (Glowacki \& Kriukova, 2018). Серед прикладів інструментів гейміфікації нами були виділені ігри, квести, пазли тощо. Так, використанню онлайн-ігор в освітньому процесі присвячено роботи Я. Ханга, П. Тернера, Е. Джонсона тощо; вебквести для здобувачів досліджували О. Квасова， Н. Лямзіна， В. Бевз тощо; використанню інших інформаційнокомунікаційних технологій у процесі викладання (пазли, ментальні карти, хмари тощо) приділено увагу О. Алексєєвої, Л. Бутенко, О. Тимощук та інших.

Формулювання цілей статті (постановка завдання). Ураховуючи актуальність якісної підготовки здобувачів вищої освіти в умовах дистанційної освіти, постає питання дослідження та групування електронних ресурсів, що можуть бути використані під час підготовки майбутніх учителів.

Результати дослідження. Відкритий доступ до сучасних інформаційних технологій породжує новий тип суспільства, який збільшує продуктивність $\mathrm{i}$ конкурентоспроможність будь-якої країни на світовому ринку й вимагає значних змін в освітній системі. В останні роки одним із пріоритетних напрямів розвитку інформаційних технологій $є$ гейміфікація, зокрема, ії впровадження в освітній сектор через удосконалення наявних освітніх платформ та створення нових ігрових навчальних програм для використання у відкритому інформаційному та освітньому середовищі. Гейміфікація стала невід'ємним сучасним інструментом освіти у 21 столітті, яким можуть користуватися викладачі як засобом посилення мотивації та залучення здобувачів до навчання (Glowacki \& Kriukova, 2018, с. 105). Популярність використання інструментів гейміфікації в закладах середньої освіти (ігри, вікторини, пазли, квести тощо) поширюється останні 5-10 років, тоді

Професіоналізм педагога: теоретичні й методичні аспекти. - Вип. 14 (Ч. 2). - Слов'янськ, 2021. 


\section{О. СТУПАК}

Використання онлайн ресурсів для підготовки майбутніх учителів

як заклади вищої освіти, орієнтуючись на академічну та професійну змістовність освітнього процесу, досить повільно просувались у цьому напрямі. Тоді як вимоги дистанційного, онлайн навчання під час вимушених карантинних обмежень стимулювали впровадження засобів гейміфікації в освітній процес здобувачів вищої освіти, зокрема в педагогічних вишах.

Широкий вибір електронних ресурсів для освіти, науки, саморозвитку на просторах Інтернету не завжди спрощує пошукувачу завдання підбору необхідного електронного ресурсу. Тому в межах нашого дослідження було підібрано низку платформ для створення електронних інструментів освітнього процесу: онлайн-ігор, вебквестів, вікторин, тестів, пазлів (див. табл.). Звичайно, представлені ресурси не обмежують усіх можливих у процесі підготовки майбутніх викладачів, але дещо систематизують та узагальнюють освітні онлайн-ресурси. Зазначимо, що більшість із них англомовна й вимагає відповідної підготовки викладачів. Ресурси можуть бути й безкоштовні, і платні, залежно від масштабів використання та функційного наповнення.

Таблиия

Електронні ресурси для створення освітніх інструментів

\begin{tabular}{|l|l|}
\hline Освітні інструменти & \multicolumn{1}{|c|}{ Види електронних ресурсів } \\
\hline Інтерактивні презентації & Nearpod, wooclap, prezi тощо \\
\hline Площа для спільної роботи & $\begin{array}{l}\text { Jamboard.google.com, Miro.com, Padlet.com } \\
\text { тощо. }\end{array}$ \\
\hline Онлайн-ігри & $\begin{array}{l}\text { Classcraft, Minecraft: Education Edition, SimCity } \\
\text { Ribbon Hero, Goosechase тощо }\end{array}$ \\
\hline Вебквести, вікторини & $\begin{array}{l}\text { Socrative, FlipQuiz, ClassDojo, Goalbook, } \\
\text { Wordwall тощо }\end{array}$ \\
\hline Тести & $\begin{array}{l}\text { Google фopми, Kahoot, Quizlet, Proprofs, } \\
\text { Classmarker, Plickers, Easy test maker тощо }\end{array}$ \\
\hline Пазли & $\begin{array}{l}\text { Arcade Game Generator, Sugarcane, Baamboozle, } \\
\text { Answerables, Jigsaw Planet, Mentimetor тощо }\end{array}$ \\
\hline Ментальні карти & $\begin{array}{l}\text { FreeMind, Mindjet Mind Manager, Free Mind Map } \\
\text { тощо. }\end{array}$ \\
\hline
\end{tabular}

Проаналізуємо представлені освітні інструменти.

Площца для спільної роботи. На онлайн-дошках можна фіксувати картинки, документи, робити записи, малювати, виконувати спільні завдання. Вони відрізняються за розмірами, можуть мати декілька сторінок, тоді ж деякі мають певні обмеження в безкоштовній версії. Водночас їх використання під час лекційних, а також практичних, семінарських занять сприяє візуалізації думок здобувачів, об'єднання їх в групи за певними характеристиками, формулюванню висновків, заключень тощо. Наприклад, дошка Miro має необмежений розмір та

(ㄱ ДВНЗ «Донбаський державний педагогічний університет» 


\section{О. СТУПАК}

Використання онлайн ресурсів для підготовки майбутніх учителів

може використовуватися як площина для висвітлення, схематичного зображення різних елементів представлення теоретичного матеріалу, а також спільної роботи здобувачів. Надавши доступ до редагування групі студентів, вони як під час практичного заняття, так і поза ним зможуть вносити свої відповіді, доповнення, корективи у виконання завдання. Перевагою також є можливість додавати картинки, відео матеріал, покликання, що може бути використане для наочності теоретичного матеріалу.

Онлайн-ігри. Навчальні комп’ютерні ігри широко використовуються для полегшення освітнього процесу під час здобуття формальної та неформальної освіти. Дослідження вказують на те, що ці ігри можуть підвищувати ефективність освітнього процесу, якщо оснащені відповідними стратегіями навчання, тобто мають чітко визначені цілі, завдання та вектор спрямування певних знань і навичок (Huang, 2019). Водночас використання навчальних комп'ютерних ігор не лише пропонує молоді віртуальний навчальний простір, але й дає їм можливість відігравати активну роль у навчанні, розвивати свої можливості вирішувати поставлені завдання або засвоювати навчальний предмет через процес практичного використання, що не завжди можуть традиційні педагогічні засоби (Huang, 2018). Отже, застосування ігрових технологій iз використанням інформаційних технологій-досягнень сприяє залученню молоді до освітнього процесу не як пасивних учасників, а як активних діячів. Серед важливих функцій, що з'єднують освітній процес і комп'ютерні онлайн-ігри, є: контекст, який відображає використання інформації в реальному житті; відтворення справжньої діяльності; численні погляди та ролі; надання оперативної оцінки навчанню; представлення пояснень у вирішальних моментах (Turner, Johnston, Kebritchi, Evans, \& David, 2018). Наприклад, онлайн-гру можна створити на веб-сайті https://www.goosechase.com (Stupak, 2020). Інтерфейс ресурсу англомовний, проте досить зручний для використання. При побудові гри є можливість додати ім'я, опис у розділі “GAME INFO”, установити обмеження часу проходження (“STAR \& STOP”) та пароль за потребою. За допомогою рейтингу активності в раельному часі можна слідкувати за відповідями учасників, давати додаткові бали чи коментувати їхні відповіді. Учасниками можуть були як команди, так й індивідуальні особи, їхня кількість відображена в розділі “PARTICIPANTS”. У випадку встановлення паролю гри, участь можуть взяти лише ті, кому буде повідомлений пароль. Завдання можуть мати різноманітній характер, відповідну кількість балів та відображаються в розділі “MISSIONS”. Гра може бути обмежена в часі, наприклад 1 день чи тиждень та розпочинаєтсья одночасно для всіх команд. Безкоштовна версія підтримує до 3х команд, але можна рзширити можливості. Виконані місії або завдання гри

Професіоналізм педагога: теоретичні й методичні аспекти. - Вип. 14 (Ч. 2). - Слов’янськ, 2021. 


\section{О. СТУПАК}

Використання онлайн ресурсів для підготовки майбутніх учителів

оцінюються різною кількістю балів. Проте модератор гри може додати бали за креативність, неординарний підхід до виконання завдань, або навпаки знизити чи взагалі не зарахувати бали за невірно виконане завдання, надавши коментар. Результат виконаного завдання підтвержується викладенеми фото, відео (до 20 сек.), текстовими матеріалами через мобільний додаток сайту. Цікавим фактом $\epsilon$ те, що гра проходить у режимі реального часу, тобто як тільки одна 3 команд виконала завдання, інша може продивитися доданий матеріал, прокоментувати, а модератор проставити бали чи додати бонуси із супроводом коментуючих тез у вигляді допису чи зображення. Такий підхід створює інтеративність гри, сприяє командній роботі та духу змагань. Ураховуючи те, що виконання місій оцінюється різною кількістю балів, перед учасниками може не ставитися завдання виконати всі місії, але перемогу здобуде команда 3 найбільшою кількістю балів. Отже, здобувачі, що беруть участь в онлайн-грі, мають можливість збудувати власну стратегію: виконати більше легких завдань чи декілька більш важких.

Вебквести і вікторини. Використання вебквестів набуває все більшої актуальності, бо успішно моделює професійно зорієнтовані завдання, виконання яких вимагає залучення колективу однодумців до аналітичної, креативної та відповідальної діяльності, зокрема за допомогою усної та писемної комунікації (Квасова \& Лямзіна, 2019). Вони сприяють інтенсифікації процесу навчання, розвитку творчого мислення молоді, формуванню вмінь працювати в умовах інформаційно-комунікаційного середовища тощо (Бевз, Годованюк, \& Дубовик, 2019, с. 100). Наприклад, створюючи вікторину за допомогою pесурсу Wordwall можна обрати різні шаблони, зокрема: ігрове шоу, кросворд, пошук пари чи слів, випадкове колесо чи пара, відкрите поле, флеш-карти тощо. Використовувати вікторини до навчальних дисциплін доречно як на початку заняття для визначення рівня розуміння попередньої теми, так і наприкінці як підсумок для засвоєння нового матеріалу. Завдання можуть мати як тексові запитання, так i картинки, фото матеріал. Також можна обмежити час на відповіді учасників, визначити рівень складності та побачити таблицю лідерів вікторини.

Пазли. Важливими дидактичними аспектами створення онлайн-пазлів $\epsilon$ практичне застосування ігрових технологій у процес навчання, що сприяє формуванню вміння концентрувати увагу, систематизувати та аналізувати наявну інформацію не лише на основі символьного подання інформації, а й сукупності візуальних об’єктів, що необхідно реконструювати (Тимощук, 2016, c. 26). Наприклад, за допомогою платформи Mentimeter можна зробити як опитування здобувачів, так і зібрати відгуки під час рефлексії як підсумку заняття, створивши діаграму, графік, хмаринку тощо. Якщо створювати 


\section{О. СТУПАК}

Використання онлайн ресурсів для підготовки майбутніх учителів

хмаринку, то відповіді учасників, що трапляються, найчастіше збільшуються за розміром, що сприяє наочному представленню думки учасників освітнього процесу.

Ментальні карти. Ще один із засобів візуалізації теоретичної інформації, що дуже актуально використовувати під час лекційних занять, є ментальні карти. Вони створюються на основі техніки візуалізації мислення та фіксації інформації, графічного зображення структури понять. Цей метод цікавий, тим, що дозволяє структурувати розумовий процес i стимулювати покрокове мислення. Ментальні карти доцільно використовувати в найрізноманітніших ситуаціях: для 3'ясування якогось питання, збору інформації, прийняття рішення, структурування нових ідей. Основу методу становить процес радіального мислення - визначається основна проблема й від неї, як від стовбура дерева, відгалужуються різні ідеї, пов’язані з нею. Ментальна карта має бути максимально образною, акуратною та різнобарвною, доповнюватися кольоровими ілюстраціями.

Наведені приклади електронних ресурсів не обмежують усі можливі, а лише представляють найбільш цікаві та ефективні. Серед інших інструментів виділяють: створення хмари слів (відображення явища чи процесу через набір ключових слів); стрічка часу, чи таймлайн (інтерактивна хронологічна шкала, що містить фотографії, тексти, ілюстрації); інфографіка (репрезентація ідей, явищ чи процесів, що передбачає ілюстративний супровід інформації, поєднання тексту й графічних зображень (Алексєєва, Бутенко, \& Курліщук, 2019).

\section{Висновки з дослідження і перспективи подальших розвідок у цьому} напрямі. Підсумовуючи вищезазначене, підкреслимо, що питання використання електронних освітніх ресурсів особливо актуальним та доцільним вбачається під час вимушеної дистанційної освіти в умовах пандемії COVID-19. На допомогу викладачам закладів вищої освіти наведена характеристика низки електронних освітніх ресурсів, що можуть бути використані під час лекційних, практичних, семінарських занять, а також для самооцінки, перевірці знань, тестування, рефлексії. Водночас наведені платформи не вичерпують всі можливі, а тому перспективою подальшого дослідження $є$ визначення ефективності кожного 3 ресурсів під час підготовки майбутніх учителів.

\section{СПИСОК ВИКОРИСТАНИХ ДЖЕРЕЛ}

1. Алексєєва, О., Бутенко, Л., Курліщук, І. (2019). Використання інформаційнокомунікаційних технологій у процесі викладання курсу за вибором «Трендспоттинг та професійне майбутнє сучасного фахівця». Інформаційні технологіï $i$ засоби навчання, 4, Т. 72, $136-151$.

2. Бевз, В., Годованюк, Т., Дубовик, В. (2019). Електронні квест-посібники у фаховій підготовці майбутніх учителів математики. Інформаційні технології і засоби навчання, 1, 100-

Професіоналізм педагога: теоретичні й методичні аспекти. - Вип. 14 (Ч. 2). - Слов’янськ, 2021. 


\title{
О. СТУПАК
}

Використання онлайн ресурсів для підготовки майбутніх учителів

111.

3. Квасова, О., Лямзіна, Н. (2019). Застосування технології вебквест у навчанні англійської мови майбутніх економістів. Інформаційні технології і засоби навчання, 6, 177185.

4. Тимощук, О. (2016). Дидактичні аспекти використання мережевих технологій та їх системні зв'язки із концепцією комп'ютерно орієнтованої педагогіки Аллана Каррінгтона. Нова педагогічна думка, 2 (86), 25-29.

5. Glowacki, J., Kriukova, Y. (2018). Gamification in higher education: experience of Poland and Ukraine. Advanced Education, 10, 105-110.

6. Huang, Y.M. (2019). Exploring students' acceptance of educational computer games from the perspective of learning strategy. Australasian Journal of Educational Technology, 35(3), $132-147$.

7. Huang, Y.M. (2018). Reason and emotion: How they drive students to play a color game. EURASIA Journal of Mathematics, Science and Technology Education, 14(5), 1911-1924.

8. Turner, P., Johnston, E., Kebritchi, M., Evans, S., David, A. (2018). Heflich Influence of online computer games on the academic achievement of nontraditional undergraduate students. Cogent Education, 5 (1). DOI: 10.1080/2331186X.2018.1437671

9. Stupak, O. (2020). Educational technologies in training future managers. Advanced Education, 15, 97-104.

\section{USE OF ONLINE RESOURCES TO TRAIN FUTURE TEACHERS}

\author{
Oksana Stupak \\ Doctor of Pedagogical Sciences, Associate Professor, \\ Department of Management, \\ SHEI "Donbas State Pedagogical University" \\ Sloviansk, Ukraine \\ ORCID ID 0000-0001-6732-4569 \\ stupak.oksana.ua@gmail.com
}

\begin{abstract}
The issue of using electronic educational resources is especially relevant and appropriate during forced distance education in the context of the COVID-19 pandemic. The article presents a theoretical analysis of electronic educational resources during the training of higher education. A wide range of electronic resources for education, science, self-development on the Internet does not always ask the searcher to select the necessary electronic resource. Therefore, the study selected a number of platforms for creating electronic tools of the educational process: interactive presentations, online boards, online games, web quests, quizzes, tests, puzzles.

Interactive presentations (Nearpod, wooclap, prezi, etc.) provide a non-standard approach to the coverage of new information, group, systematize it. At about online -boards (Jamboard.google.com, Miro.com, Padlet.com) can capture pictures, documents, take notes, draw, perform common tasks. Online games (Classcraft, Minecraft: Education Edition, SimCity Ribbon Hero, Goosechase) can increase the efficiency of the educational process if they are equipped with appropriate learning strategies, it has clearly defined goals, objectives and direction of certain knowledge and skills. The use of web quests (Socrative, FlipQuiz, ClassDojo, Goalbook, Wordwall) simulates professionally oriented tasks, the implementation of which requires the involvement of a team of like-minded people in analytical, creative and responsible activities, including through oral and written communication. Platforms for creating tests (Google forms, Kahoot, Quizlet, Proprofs, Classmarker, Plickers, Easy test maker) provide an opportunity to simplify the testing of applicants' knowledge after studying the topics. Creating online puzzles (Arcade Game Generator, Sugarcane,
\end{abstract}




\section{О. СТУПАК}

Використання онлайн ресурсів для підготовки майбутніх учителів

Baamboozle, Answerables, Jigsaw Planet) helps to develop the ability to concentrate, organize and analyze existing information not only on the basis of symbolic presentation of information. Mental maps (FreeMind, Mindjet Mind Manager, Free Mind Map) are created on the basis of the technique of visualization of thinking and fixation of information, graphic representation of the structure of concepts. Of course, the presented resources do not limit all the possibilities of electronic educational resources for future professionals, but they do systematize and generalize possible online resources.

Key words: resources; web quests; puzzles; tests; online games.

\section{REFERENCES}

1. Aleksieieva, O., Butenko, L., Kurlishchuk, I. (2019). The use of information and communication technologies in the process of teaching an elective course "Trendspotting and the professional future of the modern specialist". Information Technologies and Learning Tools, 4, Vol. 72, 136-151. 4, T. 72, 136-151.

2. Bevz, V., Hodovaniuk, T., Dubovyk, V. (2019). Electronic quest manuals in the professional training of future teachers of mathematics.. Information Technologies and Learning Tools, 1, 100-111.

3. Kvasova, O., Liamzina, N. (2019). Application of webquest technology in teaching English to future economists.. Information Technologies and Learning Tools, 6, 177-185.

4. Tymoshchuk, O. (2016). Didactic aspects of the use of network technologies and their system connections with the concept of computer-oriented pedagogy of Allan Carrington. New Pedagogical Thought, 2 (86), 25-29.

5. Glowacki, J., Kriukova, Y. (2018). Gamification in higher education: experience of Poland and Ukraine. Advanced Education, 10, 105-110.

6. Huang, Y.M. (2019). Exploring students' acceptance of educational computer games from the perspective of learning strategy. Australasian Journal of Educational Technology, 35(3), $132-147$.

7. Huang, Y.M. (2018). Reason and emotion: How they drive students to play a color game. EURASIA Journal of Mathematics, Science and Technology Education, 14(5), 1911-1924.

8. Turner, P., Johnston, E., Kebritchi, M., Evans, S., David, A. (2018). Heflich Influence of online computer games on the academic achievement of nontraditional undergraduate students. Cogent Education, 5 (1). DOI: 10.1080/2331186X.2018.1437671

9. Stupak, O. (2020). Educational technologies in training future managers. Advanced Education, 15, 97-104.

Матеріали надійшли до редакції 29.04.2021 р. 